\title{
STRATEGI PENGEMBANGAN TRANSPORTASI WISATA KURA-KURA BUS DI BALI
}

\author{
Ayu Kusuma ${ }^{1}$ I GPB. Sasrawan Mananda ${ }^{2}$, I Putu Sudana ${ }^{3}$ \\ 1ayukusuma16@gmail.com \\ Program Studi S1 Industri Perjalanan Wisata, Fakultas Pariwisata, Universitas Udayana \\ 2gusmananda@unud.ac.id \\ Program Studi S1 Industri Perjalanan Wisata, Fakultas Pariwisata, Universitas Udayana \\ ${ }^{3}$ sudana_ipw@unud.ac.id \\ Program Studi S1 Industri Perjalanan Wisata, Fakultas Pariwisata, Universitas Udayana
}

\begin{abstract}
Kura-Kura Bus is one of tourist transportation companies in Bali with public shuttle bus service in tourism route. Data analysis in this research were using SWOT and AHP analysis, with participants who have position minimal as a supervisor. Participants selected based on their expertise and relevance with this article. Based on the results of SWOT and AHP analysis to develop tourist transportation is Kura-Kura Bus, which is considered the most realistic scenario is an optimistic scenario, with the goal to be a safe and comfortable transportation. To achieve the goal, based on priority strategies that could be done by management of Kura-Kura Bus are developing unique products, finding new markets, favoring public transport services, enchance brand reputation, developing smartphone application, and cross promotion with supplier.

Abstrak: Kura-Kura Bus yang merupakan salah satu perusahaan transportasi wisata di Bali dengan layanan public shuttle bus yang memiliki rute pariwisata. Analisis data dalam artikel ini menggunakan analisis SWOT dan analisis AHP dengan responden yaitu karyawan yang memiliki jabatan minimal supervisor. Rensponden dipilih berdasarkan keahlian dan keterkaitan responden dengan permasalahan yang diteliti. Berdasarkan hasil analisis SWOT dan AHP didapat bahwa untuk mengembangkan transportasi wisata Kura-Kura Bus, skenario yang dianggap paling realistis adalah skenario optimis, dengan sasaran yang harus diprioritaskan menjadi transportasi wisata yang aman dan nyaman. Untuk mencapai sasaran tersebut, maka urutan prioritas strategi yang bisa dilakukan oleh pengelola Kura-Kura Bus adalah mengembangkan keunikan produk, mencari pasar baru, mengunggulkan layanan angkutan umum, meningkatkan reputasi merek, mengembangkan aplikasi smartphone, dan promosi silang dengan pemasok.
\end{abstract}

Keywords: strategy development; tourist transportation; kura-kura bus.

\section{PENDAHULUAN}

Transportasi merupakan suatu bidang kegiatan yang sangat penting dalam kehidupan manusia. Terutama bagi masyarakat Indonesia yang negaranya terdiri dari banyak pulau yang memungkinkan pengangkutan dilakukan melalui darat, perairan, dan udara guna dapat menjangkau seluruh wilayah Indonesia. Hal lain yang juga tidak kalah penting akan kebutuhan alat transportasi adalah kebutuhan kenyamanan, keamanan, dan kelancaran pengangkutan yang menunjang berbagai sektor ke seluruh pelosok tanah air misalnya sektor industri, perdagangan, dan pariwisata.

Perkembangan industri pariwisata di Bali menjadikan masyarakatnya sangat mengandalkan penghasilan dan peningkatan taraf hidup dari industri pariwisata. Selain aspek ekonomi yang meningkat, seharusnya aspek yang lain turut meningkat. Pariwisata tidak dapat dijadikan alasan terhadap kerusakan lingkungan dan juga aspek sosial budaya yang sangat kental 
di Bali ini hilang karena terpengaruh akan kunjungan wisatawan yang membawa banyak budaya dari daerah asalnya masing-masing.

Bali masih menjadi primadona pariwisata Indonesia dengan keindahan alam dan budaya unik yang dimilikinya. Meninkatnya kunjungan wisatawan ini adalah bukti bahwa Bali masih menjadi pilihan wisatawan untuk berkunjung. Hal ini dapat dilihat dari kunjungan wisatawan ke Bali yang terus meningkat dari tahun ke tahun seperti Tabel 1.

Tabel 1. Kunjungan Wisatawan ke Bali

\begin{tabular}{lcc}
\hline Tahun & Jumlah & $\begin{array}{l}\text { Persentase } \\
\text { Pertumbuhah }\end{array}$ \\
\hline 2012 & $2,949,332$ & $4,34 \%$ \\
\hline 2013 & $3,278,598$ & $11,16 \%$ \\
\hline 2014 & $3,766,638$ & $14,09 \%$ \\
\hline 2015 & $4,001,835$ & $6,24 \%$ \\
\hline 2016 & $4,927,937$ & $23,14 \%$ \\
\hline
\end{tabular}

Sumber : Dinas Pariwisata Provinsi Bali, 2017.

Perkembangan industri pariwisata di Bali menjadikan masyarakatnya sangat mengandalkan pemenuhan dan peningkatan ekonomi dari industri pariwisata. Selain aspek ekonomi yang meningkat, seharusnya aspek yang lain pun ikut meningkat. Jangan sampai pariwisata dijadikan alasan karena kerusakan lingkungan dan juga aspek sosial budaya yang sangat kental di Bali ini hilang karena terpengaruh akan kunjungan wisatawan yang membawa banyak budaya dari daerah asalnya masing-masing.

Transportasi menjadi alat pembawa wisatawan masuk ke dalam suatu daerah tujuan wisata. Manajemen yang baik diperlukan untuk menjaga citra baik dari daerah tujuan wisata. Mewujudkan citra baik dimata wisatawan sangat penting karena menentukan keinginan berkunjung kembali dan kepuasan wisatawan. Citra baik ditentukan oleh kepuasan wisatawan itu sendiri, untuk menciptakan kepuasan wisatwan diperlukan pelayanan yang baik. Pelayanan kepada wisatawan ini tercipta dari manajemen yang sudah tertata berdasarkan strategi suatu perusahaan demi menciptakan kepuasan wisatawan tersebut.
Permasalahan yang muncul di Bali saat ini adalah kemacetan terutama di daerah Bali bagian selatan dimana aktivitas pariwisata terpusat disana. Permasalahan ini harus dapat diatasi dengan bijaksana mengingat Bali menjadi ikon pariwisata Indonesia. Jangan sampai permasalahan ini merusak citra Bali sebagai island of paradise. Menurut Rencana Pembangunan Jangka Menengah Daerah (RPJMD) Bali 2013-2018 terdapat isu-isu strategis di bidang perhubungan yang harus dipecahkan. Berdasarkan RPJMD Bali tahun 2013-2018 tersebut dapat disimpulkan bahwa transportasi di Bali memerlukan strategi yang tepat untuk mengatasi permasalahan yang sedang dihadapi ini. Bali memerlukan suatu sistem transportasi yang dapat membawa wisatawan berwisata di Bali tanpa menimbulkan kemacetan. Sistem transportasi yang tepat untuk diberlakukan di Bali yaitu sistem transportasi umum.

Salah satu perusahaan transportasi wisata di Bali yang memiliki sistem public shuttle bus yaitu Kura Kura Bus yang memiliki keunikan tersendiri. Kura-Kura Bus merupakan layanan transportasi bus umum yang menghubungkan tempat-tempat wisata di Bali. Pusatnya terletak di Duty Free Shop (DFS) Bus Bay yang berlokasi di Jalan By Pass Ngurah Rai, Simpang Siur, Kuta. Perusahaan transportasi ini mulai menyadari akan dampak negatif dari pariwisata yaitu salah satunya kemacetan, sehingga muncul ide untuk membuat transportasi wisata yang menjadi transportasi umum yang menghubungkan tempat wisata di Bali. Desain yang unik dari bentuk bus ini yaitu berbentuk kura-kura banyak menarik minat wisatawan untuk menggunakan transportasi ini. Ide kreatif ini sangat diperlukan untuk menarik wisatawan menaiki transportasi umum sehingga wisatawan tidak lebih memilih menyewa mobil pribadi untuk kegiatan wisatanya dan tentunya dapat mengurangi kemacetan yang terjadi di Bali dengan adanya tranportasi wisata Kura-Kura Bus ini.

Strategi suatu perusahaan sangat diperlukan untuk menyusun pelayan seperti apa yang harus diberikan kepada pemakai layanan. Membuat suatu strategi dibutuhkan analisis yang tepat untuk menciptakan strategi yang benar- 
benar dibutuhkan oleh suatu perusahaan. Analisis yang harus pertama dilakukan adalah mengidentifikasi faktor internal dan faktor eksternal suatu perusahaan hingga nanti dapat dirumuskan suatu strategi. Agar strategi tersebut dapat dimaksimalkan pelaksanaannya guna mendapat kepuasan wisatawan diperlukan penempatan strategi sebagai prioritas utama ataupun strategi pendukung lainnya.

Tujuan yang ingin dicapai yaitu yang pertama untuk mendapatkan data analisis faktor internal dan faktor eksternal pada Kura-Kura Bus berupa kekuatan (strength), kelemahan (weakness), peluang (opportunity), dan ancaman (threat). Tujuan yang kedua yaitu dapat merumuskan strategi-strategi pengembagan transportasi wisata Kura-Kura Bus di Bali. Dan tujuan yang ketiga yaitu dapat menentukan prioritas strategi pengembangan transportasi wisata Kura-Kura Bus. Ruang lingkupnya difokuskan pada analisis persepsi responden yang dianggap ahli (expert), sifatnya subyektif berdasarkan persepsi dan pengetahuan para ahli tersebut. Data didapatkan dengan cara menjaring persepsi para ahli di lingkungan pengelola KuraKura Bus melalui kuisioner SWOT dan AHP.

Adapun artikel ini didukung oleh berbagai kajian penelitian terdahulu yang merupakan kajian empiris. Tinjauan penelitian sebelumnya berguna sebagai landasan untuk berpikir dan sekaligus untuk mengetahui dan mempelajari sebagai metode analisis yang digunakan dan kemungkinan dapat diterapkan oleh peneliti. Berikut adalah penelitian sebelumnya yang digunakan dalam yang terdiri dari tiga jurnal internasional, lima jurnal nasional.

Klahn (2013) meneliti tentang Measuring Tourists' Satisfaction with Public Transport in Munich, Germany. Tujuan dari penelitian ini yaitu untuk memahami kepuasan wisatawan dalam menggunakan transportasi umum dan mengetahui faktor pengaruh persepsi wisatawan. Hasil dari penelitian ini yaitu pelayanan transportasi di Munich berdampak positif terhadap wisatawan. Wisatawan sangat puas dengan sistem yang ada, jaringan koneksi, dan tingkatan layanan, sedangkan faktor harga tiket mendapat penilaian terendah. Wisatawan juga memberikan saran untuk meningkatkan tempat pemberhentian baik di terminal maupun di stasiun dan transportasi umum di Munich harap memperhatikan staf pelayanan, ketersediaan dan jarak tempat duduk, serta kebersihan.

Dyson (2003) meneliti tentang Strategic Development and SWOT analysis at The University of Warwick. Tujuan dari penelitian ini yaitu menganalisis strategi pengembangan Universitas Warwick. Hasil dari penellitian ini yaitu faktor tertinggi memiliki bias terhadap peluang dan kekuatan dan strategi yang diusulkan juga sebagian besar didorong oleh faktor-faktor tersebut. Proses perencanaan menghasilkan berbagai strategi inisiatif yang meliputi sebagian besar faktor yang diidentifikasi sebagai penting, meskipun sejumlah kecil faktor memerlukan pertimbangan lebih lanjut.

Albalate, (2009) meneliti tentang Tourism and Urban Public Transport: Holding Demand Pressure Under Supply Constraints. Tujuan dari penelitian ini yaitu untuk mengetahui tentang perencanaan kota menanggapi permintaan tambahan untuk angkutan umum perkotaan dengan memperluas layanan. Hasil dari penelitian ini yaitu intensitas pariwisata merupakan faktor permintaan untuk meningkatkan layanan angkutan umum perkotaan, namun pekotaan tampaknya tidak mengatasi tekanan ini dengan meningkatkan layanan. Pariwisata tampaknya mengerahkan eksternalitas yang positif terhadap angkutan umum tetapi juga membebankan biaya eksternal pada pengguna penduduk karena kemacetan yang disebabkan oleh kendala pasokan.

Sumiyati, dkk (2011) meneliti tentang Aplikasi Analytical Hierarchy Process (AHP) untuk Penentuan Strategi Pengembangan Subak. Tujuan dari penelitian ini yaitu mengidentifikasi kekuatan, kelemahan, peluang, dan tantangan yang dihadapi subak; menetapkan beberapa alternate strategi untuk solusi pengembangan subak; dan menetapkan strategi solusi terpilih untuk pengembangan dan keberlanjutan sistem subak ditengah pesatnya perkembangan pariwisata Bali. Hasil dari penelitian ini yaitu pengembangan subak sebagai daerah agroekowisata merupakan pilihan alternatif strategi yang mempunyai nilai paling besar dibandingkan dengan alternatif pengembangan lainnya. 
Budiartha (2011) meneliti tentang Peranan Transportasi dalam Pariwisata. Tujuan dalam penelitian itu adalah untuk mengidentifikasi faktor-faktor yang berpengaruh dalam pemilihan destinasi oleh wisatawan mananegara yang datang ke Bali dan mengevaluasi preferensi wisatawan terhadap destinasi yang dipilih. Hasil dari penelitian ini yaitu peranan infrastuktur/fasilitas transportasi menempati urutan ke dua belas, namun hasil penelitian ini dapat digunakan untuk mengotimalkan peranan transportasi dengan memprioritaskan sesuai dengan ranking pemilihan destinasi oleh wisatawan.

Saputri (2011) meneliti tentang Perancangan Strategi Pengembangan Usaha dengan Metode SWOT Analysis di Perusahaan Abon Diamond Ampel Boyolali. Tujuan dari penelitian ini yaitu untuk mengidentifikasi faktor-faktor internal dan eksternal serta kemudian menentukan strategi yang dapat diterapkan pada perusahaan Diamond untuk mengembangkan usahanya. Hasil dari penelitian ini adalah strategi yang dapat diimplementasikan yaitu dengan meningkatkan kapasitas produksi, meningkatkan pangsa pasar, memaksimalisasi harga degan volume yang optimal, memantapkan keterkaitan supplier dan lembaga penunjang, serta menetapkan jenjang karir bagi karyawan.

Tambunan (2009) meneliti tentang Posisi Transportasi dalam Pariwisata. tujuan dari penelitian ini yaitu untuk mengetahui posisi transportasi dalam pariwisata. Hasil dari penelitian ini yaitu trasnportasi ternyata merupakan syarat penting bari pariwisata karena karakteristik kunci wisatawan adalah mobilitas. Ketika mobilitas tinggi, maka trasnportasi dengan sendirinya merupakan pelopor utama bagi landasan kepedulian lingkungan. Meskipun peningkatan efisinsi dipertimbangkan, perjalanan dengan esawat udara masih sebagai pengguna energi besar bila dibandingkan dengan moda transportasi lain berdasarkan jarak per kilometernya.

Oktaviana, dkk (2011) meneliti tentang Strategi Pengembangan Transportasi antar Wilayah di Provinsi Papua Barat. Tujuan dari penelitian ini yaitu untuk mengetahui karakteristik transportasi antar wilayah dan indeks aksesibilitas wilayah yang akan digunakan untuk menyusun strategi pengembangan transportasi antar wilayah. Hasil dari penelitian ini yaitu prioritas strategi pengembangan yang direkomendasikan anatara lain: perenanaan trasportasi antar wilayah secara terpadu dan terintegrasi yang disesuaikan dengan karakteristik wilayah.

Berbagai pendapat tentang strategi dapat disimpulkan bahwa penyusunan strategi harus memperhatikan tujuan dan sasaran yang akan dicapai di waktu yang akan datang, selain itu suatu organisasi harus senantiasa berinteraksi dengan lingkungan dimana strategi tersebut akan dilaksanakan, sehingga strategi tersebut tidak bertentangan melainkan searah dan sesuai dengan kondisi lingkungan dan melihat kemampuan internal dan eksternal yang meliputi kekuatan dan kelemahan organisasinya. Oleh karena itu, strategi merupakan perluasan misi guna menjembatani organisasi dengan lingkungannya. Strategi itu sendiri biasanya dikembangkan untuk mengatasi isu strategis, dimana strategi menjelaskan respon organisasi terhadap pilihan kebijakan pokok. Strategi secara umum akan gagal, pada saat organisasi tidak memiliki konsisten antara apa yang dikatakan, apa yang di usahakan dan apa yang dilakukan.

Sebelum suatu perusahaan dapat memulai perumusan strategi, manajemen harus mengamati lingkungan eksternal untuk mengidentifikasi kesempatan dan ancaman yang mungkin terjadi. Pengamatan lingkungan adalah pemantauan, pengevaluasian dan penyebaran informasi dari lingkungan eksternal kepada orang-orang kunci dalam perusahaan. Pengamatan lingkungan adalah alat manajemen untuk menghindari kejutan strategis dan memastikan kesehatan manajemen dalam jangka panjang. Penelitian menunjukkan hubungan yang positif antara pengamatan lingkungan dengan laba (Hunger, 2003).

Manajemen transportasi berguna utnuk pemanfatan maksimum dari kapasitas angkutan, manajemen lalu lintas harus mampu mencapai efisiensi dan operasional yang tinggi, mencapai standar perawatan yang layak jalan dari kendaraan dan dapat mencapai organisasi yang 
sehat dengan standar tanggung jawab manajemen yang tinggi.

\section{METODE}

Lokasi tempat mengumpulkan data yaitu pertama terletak di Jalan Raya Kuta No. 100X, Kecamatan Kuta, Kabupaten Badung, Provinsi Bali dan satu lagi berada di Perumahan Taman Griya, Nusa Dua, Kabupaten Badung, Provinsi Bali. Kura-Kura Bus ini dipilih menjadi subjek penelitian karena sistem transportasi yang dimiliki oleh Kura-Kura Bus ini unik dan sistem ini yang harusnya dikembangkan untuk mengurangi kemacetan yang terjadi di Bali.

Apabila membahas tentang strategi tentunya ada dua faktor yang terkait, yaitu yang pertama faktor internal dan yang kedua faktor eksternal. Kedua faktor tersebutlah yang menjadi operasional variabel dalam penelitian ini. Untuk menghindari pengertian yang berbeda serta guna memudahkan pengumpulan dan analisis data yang dibutuhkan maka akan dijelaskan variabel yang digunakan dalam penelitian ini adalah sebagai berikut :

\section{Faktor Internal}

Dalam penelitian ini yang dimaksud dengan faktor internal adalah aspek-aspek atau variabel lingkungan yang berasal dari dalam perusahaan itu sendiri. Adapun yang termasuk dalam aspek-aspek tersebut adalah aspek pemasaran, aspek keuangan dan akuntansi, aspek sumber daya manusia, aspek operasional, aspek sistem informasi.

Tabel 2. Faktor Internal

\begin{tabular}{|c|c|c|c|}
\hline Variabel & $\begin{array}{l}\text { Sub } \\
\text { Variabel }\end{array}$ & Sumber & Indikator \\
\hline \multirow[t]{8}{*}{ Internal } & \multirow[t]{2}{*}{ Pemasaran } & \multirow[t]{8}{*}{$\begin{array}{l}\text { Jatmiko, } \\
2004\end{array}$} & $\begin{array}{l}\text { Tenaga penjualan yang } \\
\text { efektif }\end{array}$ \\
\hline & & & $\begin{array}{l}\text { Kemampuan } \\
\text { menghasilkan varian } \\
\text { produk }\end{array}$ \\
\hline & \multirow[t]{2}{*}{ Keuangan } & & Masalah arus kas \\
\hline & & & $\begin{array}{l}\text { Masalah saham } \\
\text { investor }\end{array}$ \\
\hline & \multirow[t]{2}{*}{ SDM } & & $\begin{array}{l}\text { Keterampilan staf yang } \\
\text { tinggi }\end{array}$ \\
\hline & & & $\begin{array}{l}\text { Latar belakang staf } \\
\text { yang beragam }\end{array}$ \\
\hline & \multirow[t]{2}{*}{ Operasional } & & $\begin{array}{l}\text { Sistem manufaktur } \\
\text { terbaik }\end{array}$ \\
\hline & & & Keunikan produk \\
\hline
\end{tabular}

\begin{tabular}{ll}
\hline $\begin{array}{l}\text { Sistem } \\
\text { Informasi }\end{array}$ & $\begin{array}{l}\text { Arus informasi antar } \\
\text { departemen baik }\end{array}$ \\
\cline { 2 - 2 } & $\begin{array}{l}\text { Tingkat reputasi merek } \\
\text { baik }\end{array}$ \\
\hline
\end{tabular}

Sumber: Hasil Penelitian, 2016.

\section{Faktor Eksternal}

Dalam penelitian ini yang dimaksud dengan faktor eksternal adalah komponenkomponen atau variabel lingkungan yang berasal dari luar ruang lingkup perusahaan. Faktor eksternal sendiri terbagi menjadi dua, yaitu lingkungan eksternal makro yang terdiri dari: faktor fisik; ekonomi; sosial; politik dan hukum; teknologi; serta demografis, sedangkan satu lagi yaitu lingkungan eksternal mikro yang terdiri dari: ancaman pendatang baru; kekuatan pemasok; kekuatan pembeli; ancaman produk pengganti; dan pesaing dalam industri.

Tabel 3. Faktor Eksternal

\begin{tabular}{|c|c|c|c|}
\hline Variabel & $\begin{array}{l}\text { Sub } \\
\text { Variabel }\end{array}$ & Sumber & Indikator \\
\hline \multirow[t]{10}{*}{ Eksternal } & Fisik & \multirow[t]{5}{*}{$\begin{array}{l}\text { Jatmiko, } \\
2004\end{array}$} & $\begin{array}{l}\text { Dampak lingkungan } \\
\text { yang baik }\end{array}$ \\
\hline & $\begin{array}{l}\text { Ekonomi, } \\
\text { Politik, } \\
\text { Hukum }\end{array}$ & & $\begin{array}{l}\text { Pengaruh kebijakan } \\
\text { ekonomi, politik, dan } \\
\text { hukum eksternal }\end{array}$ \\
\hline & Sosial & & $\begin{array}{l}\text { Membantu } \\
\text { pengembangan } \\
\text { pariwisata Bali }\end{array}$ \\
\hline & Teknologi & & $\begin{array}{l}\text { Aplikasi smartphone } \\
\text { yang canggih }\end{array}$ \\
\hline & Demografis & & $\begin{array}{l}\text { Meningkatnya } \\
\text { kunjungan wisatawan } \\
\text { ke Bali }\end{array}$ \\
\hline & $\begin{array}{l}\text { Pendatang } \\
\text { baru }\end{array}$ & \multirow[t]{5}{*}{$\begin{array}{l}\text { Porter, } \\
1993\end{array}$} & $\begin{array}{l}\text { Kompetensi dalam } \\
\text { bersaing }\end{array}$ \\
\hline & $\begin{array}{l}\text { Kekuatan } \\
\text { pemasok }\end{array}$ & & $\begin{array}{l}\text { Jumlah pemasok } \\
\text { peralatan bus }\end{array}$ \\
\hline & $\begin{array}{l}\text { Kekuatan } \\
\text { pembeli }\end{array}$ & & $\begin{array}{l}\text { Luas pasar yang } \\
\text { dijangkau }\end{array}$ \\
\hline & $\begin{array}{l}\text { Produk } \\
\text { pengganti }\end{array}$ & & $\begin{array}{l}\text { Produk perusahaan } \\
\text { lain yang memiliki } \\
\text { fungsi sama }\end{array}$ \\
\hline & $\begin{array}{l}\text { Pesaing } \\
\text { dalam } \\
\text { industri }\end{array}$ & & $\begin{array}{l}\text { Inovasi produk dalam } \\
\text { melihat pasar }\end{array}$ \\
\hline
\end{tabular}

Sumber: Hasil Penelitian, 2016.

Adapun definisi operasional variabel yang terdiri dari dua faktor, yaitu faktor internal dan faktor eksternal. Sub variabel faktor internal ditinjau menurut Jatmiko (2004) yaitu pemasaran, keuangan, SDM, operasional, dan sistem informasi. Sedangkan sub variabel faktor eksternal ditinjau menurut Jatmiko (2004), yaitu 
fisik, ekonomi, politik, hukum, sosial, teknologi, demografis dan five force menurut Porter (1993) yaitu pendatang baru, kekuatan pemasok, kekuatan pembeli, produk pengganti, dan pesaing dalam industri.

Teknik pengumpulan data yang digunakan terdiri dari observasi, studi kepustakaan, wawancara semi terstruktur, kuisioner model SWOT dan AHP. Kuisioner yang digunakan yaitu difokuskan pada analisis persepsi responden yang dianggap benar-benar memahami keadaan perusahaan.

Teknik analisis data yang digunakan dalam yaitu diawali dengan analisis faktor internal dan eksternal, kemudian dilakukan pendekatan analisis SWOT dengan interaksi matriks IFAS-EFAS untuk memperoleh beberapa alternatif strategi yang paling dominan menurut skala prioritasnya. Beberapa alternatif strategi yang dihasilkan tersebut kemudian dilakukan pemilihan skala prioritas kepentingan diantara permasalahan yang dikemukakan pada setiap levelnya dengan menggunakan analisis model AHP.

Selanjutnya dilakukan memilih alternatif strategi pengembangan transportasi wisata mana yang harus diprioritaskan dengan menggunakan pendekatan AHP. Hasil analisis AHP inilah yang akan menjadi rekomendasi alternatif strategi pengembangan dalam pengambilan keputusan untuk mencapai tujuan yang diharapkan. Berikut akan dijelaskan secara detail setiap tahapan dalam menganalisis data.

\section{Analisis SWOT}

Tahapan-tahapan dalam melakukan analisis SWOT (Rangkuti, 1997) dilakukan sebagai berikut.

Tahap pertama dalam analisis SWOT adalah melakukan identifikasi terhadap faktorfaktor internal dan eksternal di lingkungan KuraKura Bus yang dianggap berpengaruh secara positif maupun secara negatif dalam merencanakan dan melaksanakan pengembangan transportasi wisata. Tahap ini sangat penting karena hasil dari identifikasi ini akan menjadi dasar untuk kegiatan analisis berikutnya. Identifikasi faktor-faktor internal dan eksternal ini dilakukan dengan mempelajari dokumen-dokumen, kajian literatur, berita-berita yang dimuat di media, dan wawancara.

Setelah faktor-faktor internal dan eksternal telah teridentifikasi, kemudian disusun sebuah kuisioner sebagai sarana untuk mendapatkan penilaian dari responden terhadap faktor-faktor yang telah dirumuskan. Penilaian terhadap faktor-faktor yang telah diidentifikasikan dibagi menjadi dua bagian, yaitu penilaian terhadap prestasi faktor diberikan skala antara 1 sampai dengan 5. Dan penilaian urgensi (tingkat kepentingan) terhadap penanganan faktor-faktor. Penilaian pada tahap ini diberikan skala a sampai dengan $d$, yang mempunyai arti skala a berarti sangat penting untuk dilakukan penanganan; skala $b$ berarti penting untuk dilakukan penanganan; skala $\mathrm{c}$ berarti kurang penting untuk dilakukan penanganan; skala d berarti tidak penting untuk dilakukan penanganan.

Setelah kuisioner selesai disusun, maka tahap berikutnya adalah penentuan responden yang akan mengisi kuisioner tersebut. Penentuan responden dilakukan dengan mempertimbangkan keahlian dan keterkaitan calon responden dengan permasalahan yang akan diteliti.

Pemilihan responden ditetapkan secara purposive, atau ditetapkan langsung berdasarkan pengetahuan yang mereka miliki mengenai permasalahan yang sedang diteliti. Adapun responden yang diminta melakukan penilaian faktor-faktor internal dan eksternal dalam kuisioner SWOT ini yaitu dua puluh lima karyawan di lingkungan Kura-Kura Bus dengan tingkat jabatan minimal supervisor.

Setelah pengisian kuisioner, maka akan didapatkan persepsi atas faktor-faktor internal dan eksternal yang ada di lingkungan Kura-Kura Bus, sehingga kemudian akan didapatkan tabel indikator faktor-faktor intern dan ekstern. Dari penilaian terhadap faktor-faktor internal dan eksternal, langkah selanjutnya adalah melakukan identifikasi unsur-unsur yang dikategorikan sebagai kekuatan (strength), kelemahan (weakness), peluang (opportunity), dan ancaman (threat) yang dimiliki oleh Kura-Kura Bus.

Setelah faktor-faktor internal dikelompokkan menjadi kekuatan dan kelemahan, dan faktor-faktor eksternal 
dikelompokkan menjadi peluang dan ancaman, langkah selanjutnya adalah melakukan pembobotan IFAS-EFAS elemen-elemen SWOT dengan cara sebagai berikut:

1. Setiap nilai rata-rata horizontal dikurangi nilai lima sebagai nilai dari persepsi/pendapat responden yang lebih adil atas pembagian faktor internal menjadi strength dan weakness, dan faktor eksternal menjadi opportunity dan threat. Nilai 5 (lima) diambil sebagai patokan (benchmark) yang berkorelasi netral terhadap sasaran. Nilai yang dihasilkan kemudian disebut sebagai penyesuaian nilai rata-rata;

2. Nilai penyesuaian bersifat nilai mutlak;

3. Penentuan bobot dari masing-masing elemen SWOT untuk setiap faktornya dengan mengambil bobot masing-masing faktor = $100 \%$. Bobot total dari setiap elemen SWOT menggambarkan total nilai penyesuaian ratarata terhadap nilai total faktornya masingmasing;

4. Pembobotan yang dipakai sebagai bahan penilain prioritas adalah bobot tertimbang yang diperoleh dari perkalian antara bobot $\mathrm{x}$ rating. Rating diperoleh dari nilai urgensi penanganan/skala prioritas kepentingan, sesuai dengan urutan level: huruf $\mathrm{a}=4 ; \mathrm{b}=$ $3 ; \mathrm{c}=2 ; \mathrm{d}=1$.

Untuk mendapatkan prioritas dan keterkaitan antar strategi, maka dari hasil pembobotan IFAS-EFAS kuisioner SWOT untuk masing-masing indikator tersebut, dilakukan interaksi kombinasi dari strategi yang meliputi kombinasi internal-eksternal, yang terdiri dari:

1. Strategi Strength-Opportunity (SO); Interaksi kombinasi strategi SO yaitu suatu strategi yang menggunakan kekuatan untuk memanfaatkan peluang;

2. Strategi Strength-Threat (ST); Interaksi kombinasi strategi ST yaitu suatu strategi yang menggunakan kekuatan untuk mengatasi ancaman;

3. Strategi Weakness-Opportunity (WO); Interaksi kombinasi strategi WO yaitu suatu strategi yang meminimalkan kelemahan untuk memanfaatkan peluang;

4. Strategi Weakness-Threat (WT) Interaksi kombinasi strategi WT yaitu suatu strategi yang meminimalkan kelemahan untuk mengatasi ancaman.

\section{Analisis AHP}

Ciri pemecahan model AHP adalah menggunakan hirarki yang menguraikan permasalahan yang kompleks menjadi elemenelemen yang lebih sederhana. Hirarki dari metode ini dapat dibagi menjadi Goal, Skenario, Sasaran, dan Strategi. Berikut tahapan-tahapan dalam menganalisis model AHP (Saaty, 2008).

Hirarki yang akan digunakan dalam menentukan strategi pengembangan transportasi wisata yang terbaik adalah hirarki yang terdapat pada Gambar 1. Alternatif strategi yang digunakan merupakan hasil dari analisis SWOT yang telah dilakukan sebelumnya.

\section{Gambar 1. Penyusunan Hirarki Model AHP}

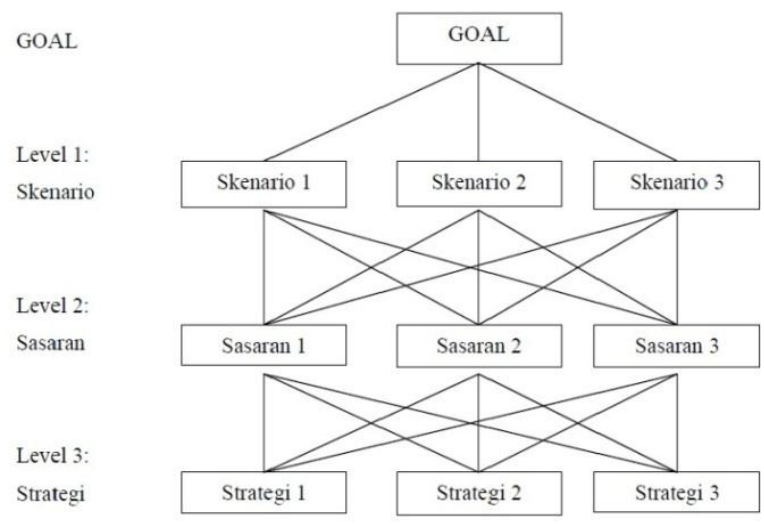

Sumber: Saaty, 2008.

Pengisian kuisioner bertujuan untuk menjaring pesepsi responden sebagai expert untuk menghasilkan data primer. Penggunaan kuisioner ini dipilih dengan cara konsensus, yaitu dengan mengumpulkan para responden secara bersamaan dalam tempat dan waktu yang sama. Responden dipilih berdasarkan pengetahuan serta pemahaman responden terhadap permasalahan yang sedang diteliti.

Penentuan jumlah expert yang disyaratkan sebagai responden untuk memberikan penilaian pada kuisioner AHP sebenarnya sangat relatif. Satu orang yang benar-benar menguasai permasalahan bisa saja memberikan hasil yang 
lebih baik daripada penilaian banyak responden yang tidak terlalu memahami permasalahan. Namun, apabila respondennya terlalu sedikit, dan apabila penilaian yang diberikan bias, maka hasil analisis secara keseluruhan akan menjadi kurang baik. Untuk menghindari hal tersebut, maka expert yang dipilih jumlahnya tidak terlalu sedikit, sehingga apabila ada penilaian yang agak janggal dapat dinetralkan dengan penilaian rata-rata sejumlah expert.

Expert yang diminta untuk menjadi responden kuisioner AHP sebanyak tujuh orang, yaitu karyawan Kura-Kura Bus dengan jabatan manajer yang dianggap paham benar akan perasalahan yang diteliti. Penilaian responden atas kuisioner AHP dilakukan dengan memberikan penilaian dari skala 1 sampai 9 . Selanjutnya akan dilakukan pengolahan data dengan menggunakan microsoft excel.

Teknik analisis data yang digunakan dalam yaitu diawali dengan analisis faktor internal dan eksternal, kemudian dilakukan pendekatan analisis SWOT dengan interaksi matriks IFAS-EFAS untuk memperoleh beberapa alternatif strategi yang paling dominan menurut skala prioritasnya. Beberapa alternatif strategi yang dihasilkan tersebut kemudian dilakukan pemilihan skala prioritas kepentingan diantara permasalahan yang dikemukakan pada setiap levelnya dengan menggunakan analisis model AHP. Selanjutnya dilakukan memilih alternatif strategi pengembangan transportasi wisata mana yang harus diprioritaskan dengan menggunakan pendekatan AHP. Hasil analisis AHP inilah yang akan menjadi rekomendasi alternatif strategi pengembangan dalam pengambilan keputusan untuk mencapai tujuan yang diharapkan.

\section{HASIL}

Kura-Kura Bus merupakan transportasi dengan lisensi transportasi umum yang menghubungkan tempat-tempat wisata di Bali. Kura-Kura Bus terdaftar dengan nama perusahaan PT. Kura-Kura, yang berkantor pusat di Jalan Raya Kuta No. 100X Kabupaten Badung, Provinsi Bali. Berdiri sejak 31 Juli 2013, PT. Kura-Kura sampai saat ini sudah memiliki beberapa produk yang pertama yaitu Kura-Kura Bus, yang kedua yaitu Kura-Kura
Guide, dan yang terbaru saat ini adalah KuraKura Shop. Perusahaan ini tergabung dengan group JTB Asia Pasific dan menggandeng mitra kerja dengan Koperasi Wahana Dharma Organda Bali. Dipimpin oleh seorang president director yaitu Mr. Michiya Mizukoshi, KuraKura Bus memiliki motto "Valuable Travel Experience" yang memiliki arti bahwa KuraKura Bus tidak hanya fokus dalam layanan transportasi saja, namun juga berupaya memberikan pengalaman yang bernilai melalui berbagai panduan informatif tentang Bali.

Setiap hari kecuali di hari raya Nyepi, Kura-Kura Bus melayani enam rute perjalanan mulai dari pukul 08.30 sampai dengan pukul 22.00 WITA. Pusatnya terletak di DFS Bus Bay yang berlokasi di Jalan Bypass Ngurah Rai, Simpang Siur, Kuta. Kurang lebih sekitar dua puluh dua armada Kura-Kura Bus beroperasi untuk melayani wisatawan yang ingin memanfaatkannya. Dalam beroperasi bus ini memiliki tiga jenis bus dengan merek Hino 300 yaitu kendaraan dengan dua belas tempat duduk untuk jalur Kuta, Legian, dan Sanur. Kendaraan dengan lima belas tempat duduk untuk jalur Seminyak, dan kendaraan dua puluh sembilan tempat duduk untuk jalur Nusa Dua dan Ubud. Kendaraan yang satu ini sudah dilengkapi dengan berbagai fasilitas seperti AC, WiFi, layar display LCD, Audio Voice Announcement System, dan juga Electric Points. Jika ingin menggunakan transportasi yang ini, maka dapat langsung menuju ke halte-halte yang sudah tersedia. Hal ini disebabkan, karena bus tidak dapat menaikkan atau menurunkan di sembarang tempat dan hanya berhenti di halte-halte yang ada tersebut.

Berdasarkan dokumen-dokumen, kajian literatur, berita-berita yang dimuat di media lokal, survei pendahuluan di lingkungan KuraKura Bus, serta gambaran umum, maka diperoleh elemen faktor-faktor internal seperti yang tertera pada Tabel 4. Setelah dilakukan penialian oleh responden dan kemudian dianalisis menggunakan microsoft excel, maka didapat hasil penilaian responden atas faktorfaktor internal dan dapat dilihat pada tabel di bawah ini. 
Tabel 4. Hasil Penilaian Responden atas FaktorFaktor Internal

\begin{tabular}{llll}
\hline No & Faktor Internal & Bobot & Kriteria \\
\hline 1 & $\begin{array}{l}\text { Mampu memberikan varian produk } \\
\text { dalam waktu singkat }\end{array}$ & 2,56 & $\mathrm{~W}$ \\
\hline 2 & Tenaga penjualan sangat efektif & 3,64 & $\mathrm{~S}$ \\
\hline 3 & Tidak ada masalah arus kas & 4,08 & $\mathrm{~S}$ \\
\hline 4 & $\begin{array}{l}\text { Tidak ada keluhan dari investor } \\
\text { mengenai saham mereka }\end{array}$ & 3,72 & $\mathrm{~S}$ \\
\hline 5 & Keterampilan staf sangat tinggi & 4,12 & $\mathrm{~S}$ \\
\hline 6 & $\begin{array}{l}\text { Latar belakang staf sangat beragam } \\
\text { perspektif, pengalaman, dan } \\
\text { pengetahuan }\end{array}$ & 2,60 & $\mathrm{~W}$ \\
\hline 7 & $\begin{array}{l}\text { Keunikan produk dapat terus } \\
\text { dikembangkan }\end{array}$ & 3,52 & $\mathrm{~S}$ \\
\hline 8 & Sistem manufaktur sangat terupdate & 4,68 & $\mathrm{~S}$ \\
\hline 9 & $\begin{array}{l}\text { Arus informasi antar departemen } \\
\text { sangat bebas dan efektif }\end{array}$ & 3,36 & $\mathrm{~W}$ \\
\hline 10 & $\begin{array}{l}\text { Tingkat reputasi merek di mata } \\
\text { pelanggan sangat tinggi }\end{array}$ & 2,68 & $\mathrm{~W}$ \\
\hline $\mathrm{Sum}$
\end{tabular}

Sumber: Hasil Penelitian, 2016.

Sedangkan untuk faktor-faktor eksternal yang didapat oleh peneliti dengan responen dan analisis yang sama, maka didapat hasil penilaian responden atas faktor-faktor eksternal dapat dilihat pada tabel berikut.

Tabel 5. Hasil Penilaian Responden atas Faktor-Faktor Eksternal

\begin{tabular}{|c|c|c|c|}
\hline No & Faktor Eksternal & Bobot & Kriteria \\
\hline 1 & $\begin{array}{l}\text { Produk memiliki dampak } \\
\text { lingungan yang sangat baik }\end{array}$ & 4,60 & $\mathrm{O}$ \\
\hline 2 & $\begin{array}{l}\text { Kebijakan ekonomi, politik, dan } \\
\text { hukum eksternal sangat } \\
\text { mempengaruhi perusahaan }\end{array}$ & 4,44 & $\mathrm{O}$ \\
\hline 3 & $\begin{array}{l}\text { Produk membantu } \\
\text { pengembangan pariwisata Bali }\end{array}$ & 4,36 & $\mathrm{O}$ \\
\hline 4 & $\begin{array}{l}\text { Aplikasi smartphone sangat } \\
\text { canggih }\end{array}$ & 3,48 & $\mathrm{~T}$ \\
\hline 5 & $\begin{array}{l}\text { Wisatawan yang datang ke Bali } \\
\text { semakin meningkat }\end{array}$ & 4,04 & $\mathrm{O}$ \\
\hline 6 & $\begin{array}{l}\text { Pesaing sangat lambat untuk } \\
\text { meniru kompetensi }\end{array}$ & 2,64 & $\mathrm{~T}$ \\
\hline 7 & $\begin{array}{l}\text { Pemasok peralatan bus sangat } \\
\text { mudah ditemukan }\end{array}$ & 2,76 & $\mathrm{~T}$ \\
\hline 8 & $\begin{array}{l}\text { Jangkauan pasar masih sangat } \\
\text { luas }\end{array}$ & 3,64 & $\mathrm{~T}$ \\
\hline 9 & $\begin{array}{l}\text { Produk pesaing dengan fungsi } \\
\text { yang sama masih belum ada }\end{array}$ & 4,12 & $\mathrm{O}$ \\
\hline 10 & $\begin{array}{l}\text { Inovasi produk masih menjadi } \\
\text { satu-satunya di Bali }\end{array}$ & 2,48 & $\mathrm{~T}$ \\
\hline
\end{tabular}

Sumber: Hasil Penelitian, 2016.

Hasil penilaian responden terhadap faktorfaktor yang dimiliki oleh Kura-Kura Bus seperti pada tabel 1 dan 2 bahwa faktor kekuatan yang memiliki nilai rata-rata paling tinggi adalah sistem manufaktur yang sangat terupdate, dengan nilai rata-rata sebesar 4,68. Hal ini, menurut penilaian responden merupakan kekuatan utama bagi Kura-Kura Bus untuk mengembangkan perusahaan. Artinya, mereka percaya bahwa sistem manufaktur mereka adalah yang terbaik di Bali jika dibandingkan dengan transportasi lainnya di Bali. Faktor kelemahan yang mendapatkan nilai rata-rata terendah adalah dapat memberikan varian produk dalam waktu singkat, dengan nilai ratarata 2,56. Hal ini menurut responden merupakan kelemahan terbesar bagi Kura-Kura Bus. Artinya, mereka belum bisa menyediakan varian produk dalam waktu singkat dikarenakan produk yang mereka luncurkan harus melalui beberapa uji coba kelayakan.

Faktor peluang yang memiliki nilai ratarata tertinggi adalah produk memiliki dampak lingkungan yang sangat baik, dengan nilai ratarata 4,60. Hal ini tentu saja disadari oleh khalayak umum bahwa Bali sebenarnya memang membutuhkan transportasi umum untuk mengurangi dampak lingkungan berupa kemacetan. Secara langsung Kura-Kura Bus membantu pemerintah Provinsi Bali untuk tetap mengembangkan pariwisata dengan menjadi perusahaan transportasi yang menghubungkan daerah-daerah wisata dan juga mengurangi dampak kemacetan yang sedang dihadapi oleh Bali sendiri. Faktor ancaman yang memiliki nilai rata-rata terendah adalah inovasi produk yang masih menjadi satu-satunya di Bali dengan nilai rata-rata 2,48. Hal ini sangat disadari oleh KuraKura Bus bahwa perusahaan pesaing mulai menginovasi produk yang hampir sama dengan Kura-Kura Bus. Artinya, kini bukan hanya Kura-Kura Bus saja yang menjalankan ide usaha "public suttle bus".

Setelah faktor-faktor internal dikelompokkan menjadi kekuatan dan kelemahan, sedangkan faktor-faktor eksternal dikelompokkan menjadi peluang dan ancaman, langkah selanjutnya adalah dilakukan interaksi kombinasi strategi internal-eksternal. Perumusan strategi-strategi tersebut disusun berdasarkan faktor internal yaitu strength dan weakness, serta faktor eksternal yaitu opportunity dan threat ke dalam matriks interaksi IFAS-EFAS SWOT seperti pada Tabel berikut. 
Tabel 6. Matriks Interaksi IFAS-EFAS SWOT

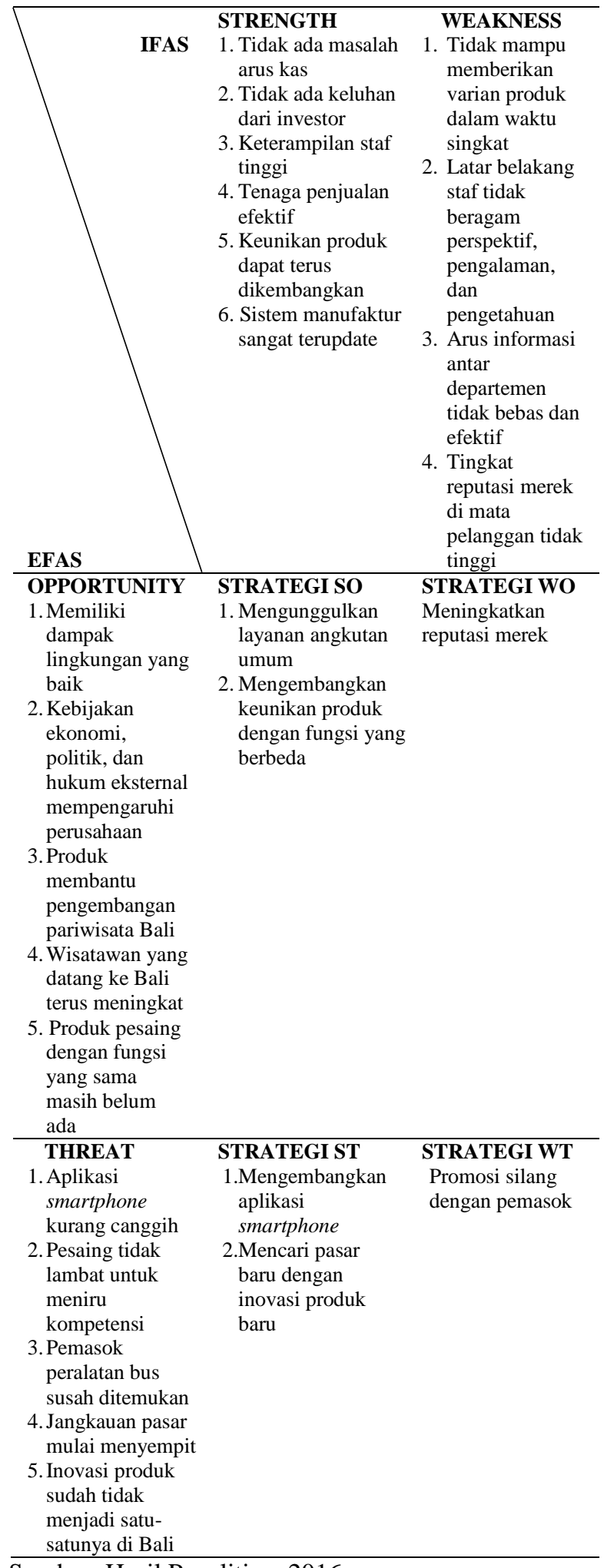

Sumber: Hasil Penelitian, 2016.
Pembobotan penilaian strategi SO, ST, WO, dan WT dilakukan untuk menentukan skala prioritas strategi. Susunan strategi alternatif berdasarkan dari penilaian responden pada kuisioner SWOT. Hasil pembobotan kuisioner SWOT terhadap strategi alternatif dapat dilihat pada Tabel 7 berikut ini.

Tabel 7. Pembobotan Hasil Kuisioner SWOT

\begin{tabular}{lll}
\hline & $\mathbf{S = 2 , 3 8}$ & $\mathbf{W = 1 , 1 9}$ \\
\hline $\mathbf{O = 2 , 0 3}$ & SO $=4,41$ & WO $=3,23$ \\
\hline $\mathbf{T}=\mathbf{1 , 4 7}$ & ST $=3,85$ & WT $=2,66$ \\
\hline
\end{tabular}

Sumber: Hasil Penelitian, 2016.

Berdasarkan hasil pembobotan strategi alternatif pada Tabel 7 maka disusun prioritas strategi berdasarkan kombinasi strategi yang memiliki nilai paling tinggi sampai yang paling rendah. Berikut susunannya dapat dilihat pada Tabel 8 berikut.

Tabel 8. Urutan Strategi Alternatif SWOT

\begin{tabular}{lll}
\hline Prioritas & Strategi & Bobot Nilai \\
\hline I & $\begin{array}{l}\text { Strength-Opportunity } \\
\text { (SO) }\end{array}$ & 4,41 \\
\hline II & Strength-Threat (ST) & 3,85 \\
III & $\begin{array}{l}\text { Weakness-Opportunity } \\
\text { (WO) }\end{array}$ & 3,23 \\
\hline IV & Weakness-Threat (WT) & 2,66 \\
\hline
\end{tabular}

Sumber: Hasil Penelitian, 2016.

Berdasarkan dari Tabel 5, strategi tertinggi adalah strategi SO diikuti urutan kedua yaitu strategi ST, dan kemudian strategi WO, lalu diurutan terakhir adalah strategi WT. Strategi-strategi SO dan ST sangat menguntungkan bagi Kura-Kura Bus karena merupakan strategi yang mengoptimalkan kekuatan perusahaan. Dapat pula dilihat pada tabel 4.7 bahwa kekuatan (strength) adalah faktor terkuat dengan nilai 2,38 dari hasil pembobotan dibandingkan dengan faktor lainnya. Sedangkan strategi WO dan WT dapat menjadi strategi alternatif lainnya berdasarkan analisis SWOT. Selanjutnya strategi-strategi ini akan dianalisis untuk penentuan prioritas dengan menggunakan analisis AHP. 
Penyusunan hirarki merupakan bagian terpenting dari model AHP, karena akan menjadi dasar bagi para responden untuk memberi penilaian secara lebih sederhana. Dengan menggunakan hirarki, diharapkan permasalahan yang kompleks akan menjadi lebih sederhana dan mudah untuk dipahami. Dalam model AHP yang digunakan yaitu hirarki yang disusun terdiri dari 4 level, dengan level puncak sebagai fokus/goal dari hirarki, yaitu: "Strategi Pengembangan Transportasi Wisata Kura-Kura Bus".

Gambar 2. Hirarki Model AHP

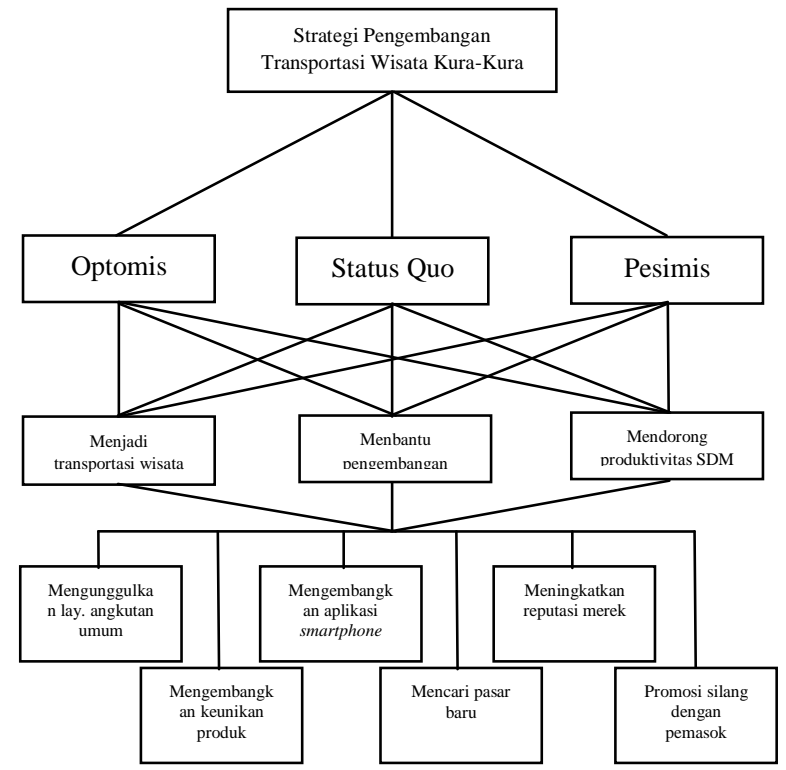

Sumber: Hasil Penelitian, 2016.

Level I adalah skenario, yang terbagi menjadi 3 kemungkinan skenario yang mungkin terjadi, yaitu Skenario Optimis, merupakan skenario masa depan, dimana lingkungan internal dan eksternal di lingkungan perusahaan Kura-Kura Bus sangat mendukung terhadap pengembangan perusahaan, atau kondisi masa depan lebih baik dari kondisi pada masa sekarang sehingga mendukung tercapainya sasaran yang diharapkan. Skenario Status Quo, merupakan skenario masa depan, dimana kondisi lingkungan internal dan eksternal KuraKura Bus tetap sama dengan kondisi saat sekarang (hampir tidak ada perubahan). Skenario Pesimis, merupakan skenario masa depan, dimana kondisi lingkungan internal dan eksternal Kura-Kura Bus lebih buruk dibandingkan kondisi pada saat ini.

Level II adalah sasaran, yang terbagi menjadi sasaran yang hendak dicapai, yaitu menjadi perusahaan transportasi wisata yang aman dan nyaman, adalah sasaran yang bermaksud untuk memberikan layanan bus wisata yang nyaman dimana keselamatan pengguna menjadi prioritas utama. Membantu pengembangan pariwisata Bali, adalah sasaran yang bermaksud untuk menyemarakkan makna budaya Bali serta atraksi budayanya. Mendorong produktivitas sumber daya manusia lokal, adalah sasaran yang bermaksud untuk mengembangkan individu-individu lokal demi tercapainya nilainilai perusahaan.

Level III adalah alternatif strategi pengembangan transportasi wisata Kura-Kura Bus yang diperoleh melalui analisis SWOT, yaitu mengunggulkan layanan angkutan umum, strategi ini bertujuan untuk memberikan pengertian kepada masyarakat di Bali maupun kepada para wisatawan yang berkunjung ke Bali bahwa untuk mengurangi kemacetan yang terjadi di Bali memerlukan suatu layanan transportasi umum dengan sistem yang terupdate dan juga bentuk yang unik untuk menarik minat pengguna. Mengembangkan keunikan produk dengan fungsi yang berbeda, strategi ini bertujuan untuk membantu pengembangan pariwisata di Bali dengan menghasilkan inovasi produk baru yang dapat menunjang perkembangan pariwisata di Bali. Mengembangkan aplikasi smartphone, strategi ini bertujuan untuk meningkatkan kepuasan pengguna terhadap pelayanan online Kura-Kura Bus sehingga tercipta repeater customer. Mencari pasar baru dengan inovasi produk baru, strategi ini bertujuan untuk menambah jangkauan pasar dengan mempeajari kebutuhan pasar saat ini sehingga muncul pasar baru dengan inovasi produk baru pula. Meningkatkan reputasi merek, strategi ini bertujuan untuk meningkatkan citra baik dari Kura-Kura Bus sehingga reputasi merek dapat terangkat. Promosi silang dengan pemasok, strategi ini bertujuan untuk menjalin kerjasama dengan pemasok, selain menjalin hubungan yang baik dengan pemasok, juga dapat menambah media promosi dari Kura-Kura Bus. 
Berdasarkan penilaian responden untuk kuisioner AHP, dapat dijabarkan bahwa skenario tertinggi adalah optimis dengan bobot 5,420. Sedangkan sasaran yang dianggap lebih penting dicapai berdasarkan dari urutan yang tertinggi adalah menjadi transportasi wisata yang aman dan nyaman, kemudian membantu pengembangan pariwisata di Bali dan yang terakhir adalah mendorong produktivitas sumber daya manusia lokal dilihat pada tabel berikut.

Tabel 9. Hasil Penghitungan Kuisioner AHP

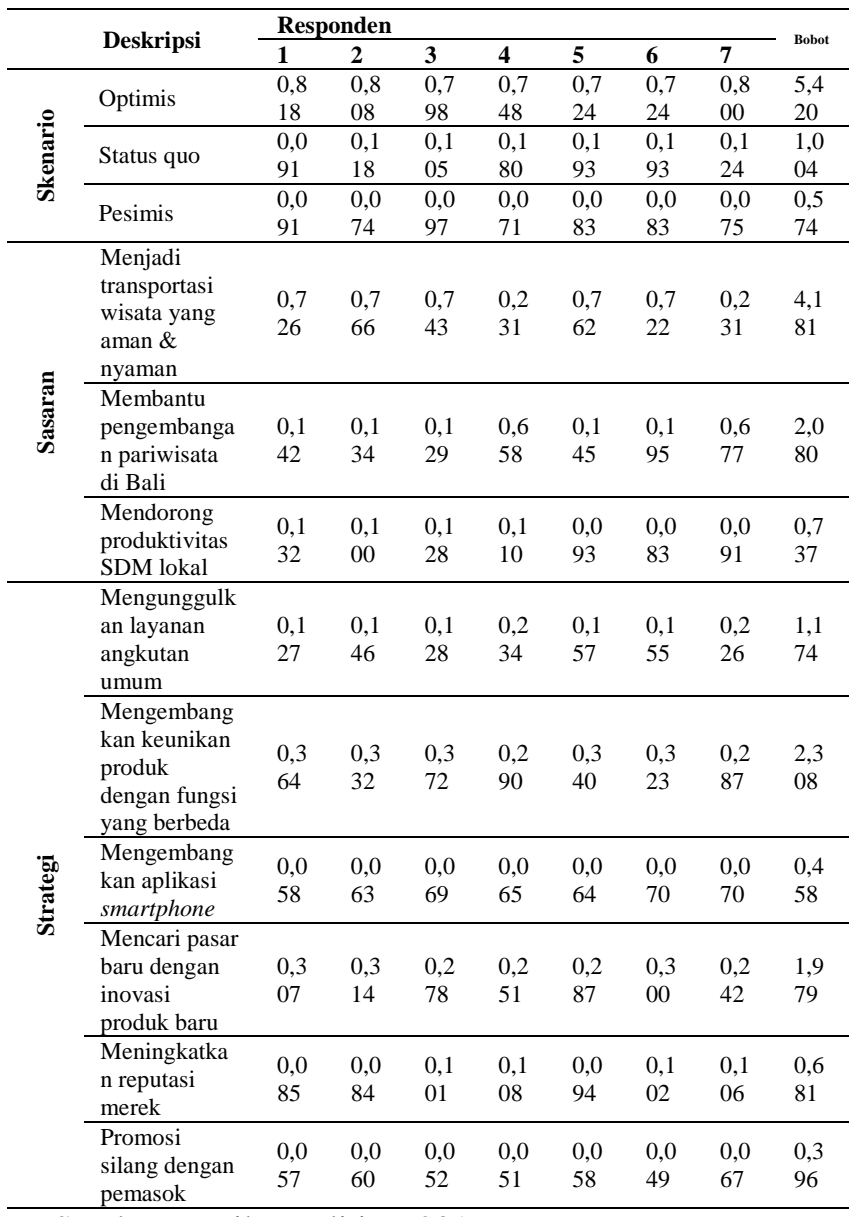

Sumber: Hasil Penelitian, 2016.

Jika dilihat dari hasil penilaian responden seperti pada Tabel 9 diatas, maka dapat dijabarkan bahwa skenario tertinggi adalah optimis dengan bobot 5,420 yang artinya para responden percaya bahwa dengan adanya faktorfaktor yang ada saat ini dapat menunjang pengembangan perusahaan. Sedangkan sasaran yang dianggap lebih penting dicapai berdasarkan dari urutan yang tertinggi adalah menjadi transportasi wisata yang aman dan nyaman dengan bobot 4,181, kemudian membantu pengembangan pariwisata di Bali dengan bobot 2,080 dan yang terakhir adalah mendorong produktivitas sumber daya manusia lokal dengan bobot 0,737. Kemudian untuk urutan prioritas strategi dapat dilihat pada Tabel 10.

Tabel 10. Urutan Prioritas Strategi Pengembangan

\begin{tabular}{lll}
\hline Prioritas & Strategi & Bobot \\
\hline I & Mengembangkan keunikan produk & 2,308 \\
\hline II & Mencari pasar baru & 1,979 \\
\hline III & $\begin{array}{l}\text { Mengunggulkan layanan angkutan } \\
\text { umum }\end{array}$ & 1,174 \\
\hline IV & Meningkatkan reputasi merek & 0,681 \\
\hline V & $\begin{array}{l}\text { Mengembangkan aplikasi } \\
\text { smartphone }\end{array}$ & 0,458 \\
\hline VI & Promosi silang dengan pemasok & 0,396 \\
\hline
\end{tabular}

Sumber: Hasil Penelitian, 2016.

Berdasarkan Tabel 10 dapat dilihat bahwa para responden percaya dengan adanya faktor internal dan faktor eksternal saat ini, strategi yang harus diproritaskan pertama yaitu mengembangkan keunikan produk, kemudian yang kedua mencari pasar baru, yang ketiga mengunggulkan layanan angkutan umum, yang keempat meningkatkan reputasi merek, yang kelima mengembangkan aplikasi smartphone dan yang terakhir promosi silang dengan pemasok. Dengan demikian dari hasil penilaian responden dapat disimpulkan bahwa dalam rangka pengembangan transportasi wisata KuraKura Bus, skenario yang dianggap paling realistis adalah skenario optimis, dengan sasaran yang harus diprioritaskan menjadi transportasi wisata yang aman dan nyaman. Cara mencapai sasaran tersebut, maka urutan prioritas strategi yang bisa dilakukan oleh pengelola Kura-Kura Bus adalah seperti yang tertera pada Tabel 10 .

\section{PEMBAHASAN}

Berdasarkan dua analisis yang telah dilalui, maka sasaran yang menjadi tujuan dari pengembangan transportasi wisata Kura-Kura Bus yaitu menjadi transportasi wisata yang aman dan nyaman merupakan salah satu misi dari Kura-Kura Bus. Misi ini dianggap oleh para 
responden merupakan sasaran yang harus diprioritaskan agar transportasi wisata KuraKura Bus ini dapat terus berkembang terutama di Bali. Berdasarkan pengolahan data mengunakan metode AHP, untuk mencapai sasaran menjadi transportasi wisata yang aman dan nyaman, didapatkan prioritas strategi pengembangan yaitu sebagai berikut.

\section{Strategi I}

Mengembangkan keunikan produk dengan fungsi yang berbeda, strategi ini bertujuan untuk menambah inovasi produk baru. Produk yang ada saat ini sudah cukup unik, akan tetapi berjalannya waktu saat ini perusahaan lain dapat meniru produk yang ada saat ini. Jika produk tidak dikembangkan, maka bisa jadi produk yang dimiliki Kura-Kura Bus saat ini dikembangkan oleh perusahaan pesaing lain. Strategi ini adalah strategi menangkap peluang dengan menggunakan kekuatan yang dimiliki.

\section{Strategi II}

Mencari pasar baru dengan inovasi produk baru, strategi ini bertujuan untuk menunjang strategi pertama yaitu mengembangkan produk baru. Setelah strategi pertama dijalankan, maka strategi ini mengikuti untuk dikerjakan dan juga berguna untuk memperluas jangkauan pasar yang ada saat ini. Strategi ini muncul karena melihat ancaman yang ada dan dengan memanfaatkan kekuatan yang dimiliki.

\section{Strategi III}

Mengunggulkan layanan angkutan umum, strategi ini diharapkan nantinya dapat mengurangi kemacetan yang terjadi di Bali saat ini. Seperti yang dipaparkan pada latar belakang sebelumnya bahwa di Bali saat ini kepadatan lalu lintasnya sudah cukup tinggi, maka diperlukan solusi transportasi yang dapat mengatasinya. Kesadaran untuk menggunakan angkutan umum perlu ditingkatkan, tidak hanya untuk wisatawan tapi juga masyarakat. Maka dari itu strategi ini muncul untuk membantu pemerintah mensosialisasikan bahwa solusi untuk mengatasi kemacetan yang ada di Bali adalah dengan mengunakan layanan angkutan umum. Dengan mengunggulkan yang dimiliki oleh Kura-Kura Bus yaitu manufaktur yang terupdate dan bentuk bus yang unik, diharapkan wisatawan maupun masyarakat mulai mempercayai trasportasi umum dan mulai beralih dari transportasi pribadi.

\section{Strategi IV}

Meningkatkan reputasi merek, strategi ini bertujuan untuk menanamkan citra baik pada wisatawan maupun masyarakat Bali sendiri. Adanya branding yang mencolok pada dekorasi bus saat ini dirasa masih belum cukup, sehingga diperlukan strategi lain untuk meningkatkan reputasi Kura-Kura Bus. Kura-Kura Bus merupakan alat transportasi yang membantu pengembangan pariwisata Bali, dan juga membantu pemerintah mengurangi kemacetan yang ada di Bali ini. Branding dengan menggunakan media lokal juga dapat membantu meningkatkan reputasi merek karena salah satu misi Kura-Kura Bus adalah membantu mengembangkan pariwisata Bali.

\section{Strategi V}

Mengembangkan aplikasi smartphone, strategi ini betujuan untuk mempermudah pengguna Kura-Kura Bus untuk menggunakan layanannya. Aplikasi yang ada saat ini sudah dianggap membantu pengguna untuk menemukan Kura-Kura Bus, akan tetapi dengan semakin berkembangnya teknologi informasi saat ini juga menuntut pihak Kura-Kura Bus mengembangkan aplikasinya untuk semakin mudah digunakan dengan adanya fitur-fitur pendukung. Misalnya saja dapat membeli tiket langsung via aplikasi.

\section{Strategi IV}

Promosi silang dengan pemasok, strategi ini bertujuan untuk menjalin kerjasama promosi dengan pemasok. Strategi ini berada di strategi terakhir karena pihak Kura-Kura Bus masih menggap promosi silang belum efektif dilakukan oleh pihaknya. Strategi ini mungkin akan dilakukan oleh Kura-Kura Bus apabila memang ada permintaan dari pihak pemasok dan hal itu sama-sama menguntungkan dua belah pihak. 


\section{SIMPULAN DAN SARAN}

\section{Simpulan}

Artikel ini menghasilkan strategi-strategi melalui analisis SWOT dan diurutkan berdasarkan prioritasnya melalui metode AHP guna mengembangkan transportasi wisata KuraKura Bus di Bali.

Faktor-Faktor internal yang dimiliki oleh Kura-Kura Bus yaitu tenaga penjualan yang efektif, kemampuan menghasilkan varian produk, masalah arus kas, masalah saham investor, keterampilan staf yang tinggi, latar belakang staf yang beragam, system manufaktur terbaik, keunikan produk, arus informasi antar departemen baik, dan tingkat reputasi merek. Sedangkan faktor-faktor eksternal yaitu dampak lingkungan yang baik, kebijakan pemerintah, membantu pengembangan pariwisata Bali, aplikasi smartphone, kunjungan wisatawan, kompetensi dalam pesaing, jumlah pemasok, luas pasar yang dijangkau, produk perusahaan lain yang memiliki fungsi yang sama, dan inovasi produk dalam melihat pasar.

Strategi-strategi yang dapat digunakan oleh Kura-Kura Bus antara lain yaitu mengunggulkan layanan angkutan umum, mengembangkan keunikan produk dengan fungsi yang berbeda, mengembangkan aplikasi smartphone, mencari pasar baru dengan inovasi produk baru, meningkatkan reputasi merek, dan promosi silang dengan pemasok.

Strategi yang menjadi prioritas utama berdasarkan hasil yang didapat adalah dengan menembangkan keunikan produk dengan fungsi yang berbeda sehingga misi yang dimiliki oleh Kura-Kura Bus dapat terlaksana.

\section{Saran}

Saran yang dapat penulis sampaikan adalah sebagai berikut:

1. Diharapkan nantinya Kura-Kura Bus memikirkan cara untuk dapat memberikan varian produk dalam waktu singkat dengan tujuan untuk meningkatkan kepuasan penggunanya.

2. Staf diharapkan nantinya diberi bekal pengetahuan tentang pariwisata Bali secara merata, dikarenakan staf yang ada memiliki latar belakang yang beragam. Terutama untuk staf yang berhadapan langsung dengan pengguna jasa. Hal ini dapat membatu apabila ada wisatawan yang bertanya tentang pariwisata Bali, maka dapat menjawab dengan benar.

3. Diharapkan nantinya Kura-Kura Bus memiliki satu kantor saja, walaupun harus ada gedung yang berbeda antara staf office dengan bagian operasional asalkan jaraknya tidak terlalu jauh. Hal ini dapat mempererat jalur komunikasi antara bagian office dan bagian operasional dan juga meminimalisir adanya missing communication internal. Komunikasi antar staf sangat penting untuk mendukung perkembangan transportasi wisata Kura-Kura Bus.

4. Diharapkan nantinya Kura-Kura Bus dapat menjalin kerjasama dengan media lokal guna meningkatkan reputasinya baik dimata wisatawan maupun masyarakat Bali. 


\section{Kepustakaan}

Anonim. www.disparda.baliprov.go.id diakses pada 22 Maret 2017. www.kura2bus.com diakses pada 6 Juni 2016.

Albalate, Daniel. 2009. Tourism and Urban Transport: Holding Demand Pressure unde Supply Constraints. Barcelona: Tourism Management xxx.

Budiartha, Nyoman. 2011. Peranan Transportasi dalam Pariwisata. Badung: Jurnal Ilmiah Teknik Sipil Volume 15.

Dyson, Robert. 2003. Strategic development and SWOT analysis at the University of Warwick. United Kingdom: European Journal of Operational Research 152.

Hunger, David K. 2003. Manajemen Strategis. Yogyakarta: Penerbit Andi.

Jatmiko, RD. 2004. Manajemen Stratejik. Malang: UMM Press.

Klahn, Diem Trinh Le. 2013. Measuring Tourist' Statisfaction with Public Transport in Munich, Germany. Munich: International Journal of Business and Applied Sciences.

Oktaviana, dkk. 2011. Strategi Pengebangan Transportasi Antar Wilayah di Provinsi Papua Barat. Malang: Jurnal Rekayasa Sipil/Volume 5.

Pemerintahan Provinsi Bali. 2012. Rancangan RPJMD Bali 2013-2018. Denpasar.

Porter, Michael E. 1993. Keunggulan Bersaing Menciptakan dan Mempertahankan Kinerja Unggul. Jakarta: Erlangga.

Rangkuti, Freedy. 1997. Analisis SWOT Teknik Membedah Kasus Bisnis. Jakarta: Gramedia Pustaka Utama.
Saaty, L.Thomas. 2008. Decision Making With The Analitytic Hierarchy Process. Pittsburgh: Services Scinces Vol I.

Saputri, Eni Dewi. 2011. Perancangan Strategi Pengembangan Usaha dengan Metode SWOT Analysis di Perusahaan Abon Diamond Ampel Boyolali. Surakarta: Universitas Sebelas Maret.

Sumiyati, dkk. 2011. Aplikasi Analytical Hierarchy Process (AHP) untuk Penentuan Strategi Pengembangan Subak. Badung: Agritech Volume 31.

Tambunan, Nani. 2009. Posisi Transportasi dalam Pariwisata. Jakarta: Majalah Ilmiah Panorama Nusantara edisi IV. 